\title{
From Crèvecoeur to Castorland: Translating the French-American Alliance in the Late Federalist Era
}

John A. Gallucci

\section{(2) OpenEdition}

\section{Journals}

Electronic version

URL: https://journals.openedition.org/ejas/8920

DOI: $10.4000 /$ ejas. 8920

ISSN: 1991-9336

Publisher

European Association for American Studies

\section{Electronic reference}

John A. Gallucci, "From Crèvecoeur to Castorland: Translating the French-American Alliance in the Late Federalist Era", European journal of American studies [Online], 6-2 | 2011, document 2, Online since 04 April 2011, connection on 08 July 2021. URL: http://journals.openedition.org/ejas/8920 ; DOI: https://doi.org/10.4000/ejas.8920

This text was automatically generated on 8 July 2021.

Creative Commons License 


\title{
From Crèvecoeur to Castorland: Translating the French-American Alliance in the Late Federalist Era
}

\author{
John A. Gallucci
}

\section{Introduction}

1 With this essay, I wish to suggest how a little-known text, the Castorland Journal, may help us read as an exercise in translation Crèvecoeur's Journey into Northern Pennsylvania and the State of New York. ${ }^{\mathrm{i}}$ My focus is on the ending of this lengthy work. This ending is in strong contrast with its beginning. At the beginning, Crèvecoeur comes very close to speaking in his own voice, identifying, for example, the author of the "Dedication" with the letters "SJDC." At the end, Crèvecoeur writes from the persona of the visitor Gustave Herman. At the beginning of the Journey, there are references to the public leaders of France and the United States. The Journey begins with the striking "Dedication" to George Washington. The translator's foreword refers directly to France's contemporary political and public affairs and in particular to "the Washington of France," Napoleon. In contrast, at the end of Volume III, we find a more private, subdued tone as the narrative is interrupted by Gustave Herman's announcement that he has just received a letter from his father, and that he must therefore return to Europe. In taking leave of America, Herman is profuse in his thanks to his friend for his American hospitality, and the final word of the narrative is that of personal friendship. And in particular, at the end of Volume III, Herman is profuse in his enthusiasm over a certain place in northern New York named "Castorland." What does this reference mean? 


\section{The Translator's Absence}

2 Let us recall how the Journey is introduced. According to the foreword, the Journey is a translation of a manuscript recovered from a shipwreck. The transmission of this text involves three people: the unknown author, the merchant who purchased items recovered from the shipwreck, and the translator, who has himself written this foreword.

3 As one knows or soon infers, the Journey is in fact the work of the author Crèvecoeur and not a real translation. For Crèvecoeur, the claim of translation is part of this scenario of discovery that establishes the reality, or rather, the credibility, of the Journey. One translates something pre-existing: The very fact that a text is called a translation naturally creates the assumption that prior to the act of translating another text did in fact exist. The Journey as translation is therefore, we assume, more truthful, more grounded in reality.

4 However, there is a moment in the Journey when the Translator is absent and another person takes his place. I am referring to the very end of Volume III where we find 1) Gustave Herman's letter of farewell to his American friend; and 2) the notes that are supplied for the elucidation of this letter.

5 In this letter, in mentioning the bursting activity which he had witnessed during his travels in the United States, Herman singles out New York State and, in particular, various place-names in northern New York for attention (the numbers in parentheses refer to notes supplied by Crèvecoeur):

Sir, I have received a letter from my father ....

This vast ensemble is like an everchanging picture to which new lines and new colors are added every year. Without mentioning other states, what changes have taken place in New-York since our journey to Onondaga in 1789! Scarcely was the country of the Tenezee then known, even less those of the new Catarakouy, Castorland (1), Oswegatchie, Rieland, etc., the towns of Little Falls, Whiteston, Barnewelt, Roterdam, Rome, Leyden, Castorville, etc., were not even founded then, nor were the canals of Wood-Creek and Stanwich dug. Not a single dwelling as built on the banks of the great bay at Niahoure (2)....ii

A total of fourteen names are listed at the beginning of Herman's letter, although the "etc." implies that more could be listed. Two of these place names, Castorland and Niahouré, are given individual notes by the "Editor." In other words, the names Castorland and Niahouré are singled out for special attention.

7 These explanatory notes are framed in a careful and deliberate way, and it is here that we find that the Translator has been absent. In an additional note to his note, Crèvecoeur explains the source for the Editor's information on Castorland. He writes:

Notes on the Letter from Mr. Herman*

....

* The Editor, having learned that one of his friends had just received a letter from the agent in charge of the settlement of a large concession of lands which he [i.e. the friend] owns in this part of the State of New-York, thought that it would not be disagreeable to the Translator of this Work, absent for some time, nor to the public, to see inserted here several of the interesting details contained in this letter, dated the 4 th of April last.iii

8 We see from this note to the note on Herman's letter, that this information comes to the Editor and into the Journey independently of the found, "original" manuscript. We 
have a communication transmitted by three people: We have the agent (in America), the land-owning friend of the Editor, and then the Editor himself, who has taken it upon himself to add this information, as the Translator, for some unspecified reason, happens to be "absent for some time." It would seem then that this "Editor" is to be distinguised from the Translator/Publisher of the title page, although all of these personae refer of course to Crèvecoeur. In other words, if I am reading this note correctly, the notes on Castorland are the only part of the Journey that is not portrayed as a translation. The Editor, it appears, is simply passing on information received from sources other than those that the Translator/Publisher used.

9 The manner then in which the "Editor" provides these "interesting details" adds to the credibility and realism of the Journey overall, as the Editor appears to corroborate the work of the unknown Author (and of the Author's Translator) by supplying this information on Castorland.

10 Crèvecoeur clearly went to some trouble to make these "interesting details" on "Castorland" a convincing part of his narrative: first, by introducing them in a natural way, through the person of Gustave Herman, an eyewitness who had, it is implied, "seen" them; then, through the explanatory notes that add realism from further explanation; finally, through the alleged provenance of this information: It came to the Editor directly from the person on site in America, and so was not part of the found manuscript or its translation. The mention of Castorland at the end of the Journey is certainly deliberate and strategic (although Castorland is mentioned in passing early in the Journey), iv and is clearly meant to leave in the reader's mind the notion of a prosperous region that only needs a few more settlers to prosper.

11 Why is there such attention to Castorland? It is here that I wish to introduce another text, the Castorland Journal, and explore its relation to Crèvecoeur's Journey.

\section{The New York Company}

12 Let us consider some background. "Castorland" was the name given to a large tract of land along the Black River in northern New York. This land was purchased in 1793 by a French land company, La Compagnie de New York, which had been formed in France during the critical years 1792 and 1793. Involved in this business transaction were leading American and French speculators, such as William Constable; his partner, Alexander Macomb; and especially, James Donatien Le Ray de Chaumont, the son of the Le Ray de Chaumont who, during the American Revolution, had provided a home in Paris for Benjamin Franklin. Gouverneur Morris, the American minister to France, was an associate of Constable, who encouraged this and other speculations. ${ }^{v}$

13 It so happens that Crèvecoeur was an investor in the New York Company and certainly involved in its affairs. His name is found in the list of stockholders. Out of forty-one investors, he is listed third. The legal owner of the land, Pierre Chassanis, holding 204 shares, is listed first; Le Ray de Chaumont, second, with 100 shares. Michel St. John de Crèvecoeur-that is how he is named in this list-held a more modest 10 shares of stock. The fact that he is listed third suggests that he played an important role in the New York Company, even though other investors held more stock than he did. ${ }^{\mathrm{vi}}$

14 In 1793, the New York Company sent to America two agents, or "commissioners," Pierre Pharoux and Simon Desjardins. Besides beginning the work of surveying, 
building cabins and roads, they were required by the Company's by-laws to keep a journal of their work. The result is a daily chronology of their work and travels in America, a journal in the fullest sense of the word. The Journal provides some interesting biographical information then on Crèvecoeur and on his family. One of his sons for example visited the region and appears in the Journal. The Journal was first discovered in the mid-nineteenth century by the historian Franklin B. Hough and has been used sporadically since by historians. vii

15 The Castorland Journal is a narrative of hard work and disappointment. If one may give a plot to this chronological narrative, one could say that the basic story involves the discovery that the boundaries of the tract of land purchased by the New York Company were based on mistaken information; the actual tract turned out to be much less than promised. As a result, Pharoux and Desjardins would seek redress for this injustice. The story is quite heartbreaking. Eventually, Pharoux would lose his life in Castorland, drowning in the Black River in his haste to travel to Kingston, Canada. Desjardins would be replaced by another director and leave Castorland in bitterness. With his departure, the Journal comes to an end. The New York Company would continue to promote Castorland in subsequent years.

16 This promotion of Castorland is clearly one of the reasons for its inclusion in the Journey. Crèvecoeur is promoting a place, a settlement, a speculation, and this feature of his work has been underscored by scholars. viii Yet the obvious inference-that Crèvecoeur is simply promoting his own self-interest-is, I believe, insufficient to explain Crèvecoeur's interest in Castorland or its inclusion in the Journey. For example, as we have seen, he held only ten shares of stock, well below the average number of 44 shares per shareholder (forty-one stockholders and 1808 shares).

17 I suggest that Crèvecoeur has, besides financial reasons for the promotion of Castorland, more generous reasons that have to do with the general political relations between his adopted and native lands in the years following the American and French Revolutions. I base this interpretation on Crèvecoeur's idea of alliance; and on what I take to be a larger rhetorical goal of the Journey.

\section{Crèvecoeur's Idea of Alliance}

18 In the Journey, the word "alliance" is used in an extremely interesting way (the upper and lower case Roman numerals in square brackets refer respectively to the Volume and Chapter number of the Journey):

1. alliance between English and Iroquois [I: i]: Sir William Johnson: "This alliance contributed a great deal toward the progress of settlements, toward the peace and security of the inhabitants of the colony of New-York, and facilitated the acquisition of lands, in proportion to the greed of the Governors or companies of speculators."ix

2. alliance between French and Missagués [I: i]: "Shortly after their settling at Montreal, the French made an alliance which, as it turned out, became very useful to them, when they were attacked by the English and Mohawks. Since this ancient time, they have not ceased being their constant and faithful allies, until the conquest of Canada."x

3. alliance between France and the United States: [III:x: note 7]: "Finally, came the surrender of Burgoyne, which decided the alliance with France, an alliance that contributed so powerfully to the surrender of Yorktown and to peace." ${ }_{\mathrm{xi}}$ 
4. alliance Great Britain and the Six Nations: [III: xi]: "The close alliance which Great Britain contracted at the time with the Six Confederated Nations, an alliance which has persisted [to] the beginning of the Revolution,permitted the inhabitants to extend their clearings, build towns in the interior and multiply their number. It experienced in the course of all this a great expansion by the successive arrival of Germans, Irish, Flemish, Palatins, and French driven from their country by the revocation of the Edict of Nantes, that shameful blot on the reign of Louis XIV."

19 These examples are presented in a discrete fashion. For example, Crèvecoeur gives no more space to the French-American alliance than he does to the other examples he provides. In fact, with the last example mentioned, he goes out of his way to criticize his native land's treatment of its own citizens in a period of crisis-the expulsion of the Huguenots under Louis XIV-a criticism that strikes me as an indirect comment on the French Revolution and the émigrés.

20 At the same time, Crèvecoeur has firm ideas on the value of an "alliance" that are clearly enunciated. These examples are strictly parallel not only in the presentation of historical fact; but also in the emphasis on the clear, real, positive effects of an alliance on social progress and individual well-being. Each of these examples is strictly parallel to the others in this respect: "contributed a great deal," "very useful," "contributed so powerfully," "permitted the inhabitants to extend their clearings ... build ... multiply ...." In each case, an alliance is greater than the sum of its parts and brings into being those values cherished by Crèvecoeur: economic progress, tranquility, social wellbeing, peace, a halt to cannibalism.

21 We see how the New York Company viewed the alliance in a fascinating episode in the Journal. Pharoux and Desjardins are traveling via the Mohawk River and Oswego and Lake Ontario to their lands at the mouth of the Black River in the Bay of Niahouré. But Oswego is still held by the British, and the commander of the British fort at Oswego claims that the French authors of the Journal may not proceed any further. One of the authors, Pierre Pharoux, counters this argument by making explicit reference to the French-American alliance, using it as a quasi-legal document to argue, successfully, that he and his French companions, as allies of the Americans, should be allowed to pass Oswego and go on to their lands.

22 By the author's placing this episode within the larger political context of 1793, we see that the Castorland émigrés, while successful in this particular instance, are in fact making a belated argument for alliance. In fact, the French-American Alliance was beginning to undergo a drastic re-evaluation just as the Castorland settlement was begun. The New York Company had assumed the alliance to be as intact in the autumn of 1793 as it was in 1778 and 1779, when, in fact, the American government had already begun insisting on a foreign policy based on neutrality. In the critical year 1793, there is the antagonizing personality of Genet; the conflicts between Hamilton and Jefferson; the statements on neutrality by Washington. ${ }^{\text {xii }}$

23 There is irony in the personal circumstances of these émigrés, who-like the Huguenots who were "driven from their country"-arrive at a time when several hundred miles away, in Philadelphia, the alliance was being reconsidered. This episode in the Journal, and the Journal as a whole, become an example of a narrative of disappointment in the attempt to use the French-American alliance as a sustaining cultural or political reality at a time when relations between the two countries were worsening. 
24 Crèvecoeur's Journey was written, I contend, at least in part, to repair this disappointment and, in the new historical context of the late 1790s, to lay the ground for an invitation to a restoration of an alliance. And the discussion of Castorland in the Journey seems meant to be a possible starting point for such a restoration, if not at the national level of foreign policy, at least as a private endeavor open to the citizens of the two Republics.

\section{Towards a New Alliance}

These ideas of social well-being are emphasized in the Notes to Mr. Herman's Letter. These "Notes" take up ten pages, pages 399-409 of volume III of the Journey, and extend over a total of seventeen paragraphs. The author of the Note on Castorland is presumably the Agent, who is addressing the "Friend" of the "Editor," but this is not entirely clear. Overall, the note on Castorland reads like a typical land prospectus. We find at the outset a description of Castorland's boundaries and then an accumulation of details on its richness and potential. There is the potential for building factories; natural resources such as prairies; the types of trees suggest rich land; the British in Canada will not intervene to oppose settlement; families are already living on the land and developing Castorland; communication by water is accessible; the Bay of Niahouré is on “coastal lands," etc.

Yet besides these remarks on Castorland's prosperity, there are other remarks that are typical of Crèvecoeur's style in the Journey and in his Letters, for example the paradigmatic, totemic function of the animals found in Castorland, the beaver and the wolf:

of all the beaver colonies that occupy this land have built dams, only a few scattered families remain, for we have destroyed this little society, image of happiness, in whose bosom reigned the most perfect order, peace, prudence, precaution, and industry. The wiliest wolves, more warlike than the beavers, live at our expense and until now have avoided our deadly lead. ${ }^{\text {xiv }}$

As is typical, Crèvecoeur personifies the beaver. This animal has colonies and families; these families exist in societies and know happiness; their qualities are those of those humans who are singled out by Crèvecoeur in the Journey as examples of human leadership. One also thinks of the extended personification of the beaver, the castor, in Volume II, chapter 1, when the Manitou creates the race of beavers-called Amickfrom a human being (with an obvious echo of the French word for friend, "ami"). Likewise, in this note on Castorland, one finds a typical reflection on human nature: man is a "tyrant." This definition is not mere name-calling. Crèvecoeur provides in the Journey, as in Crèvecoeur's Letters from an American Farmer, serious reflection on human nature. The definition of man as "tyrant" is meant to raise the serious moral and political question of how to live in tranquillity and peace, given this essential character of man. This brief passage transforms the whole landscape of the Castorland settlement into a symbolic-if that is the word-narrative of moral and political conflict in which a small yet ideal example of society is destroyed and subjected to further menace.

Besides the remarks on the economic potential of Castorland, besides the story of the families of beaver and the implications for human nature, these notes give special attention to the death of a "young man" of many talents and someone who would have been key to the success of the settlement. This is a direct reference to the death of 
Pierre Pharoux, who had begun in the United States a brilliant career as architect and engineer. The Notes in the Journey mention him twice, the second time, by the initials "M. P." (the initials stand for Monsieur Pharoux):

29 An event as unfortunate as it was unexpected, has retarded considerably the prosperity of this colony. The death occurred of a young man, full of talents, whom the Castorland company had sent from Paris to make a country wild, and until then unknown, suitable for a newborn settlement, divide the lands, open communications, begin plowings, build bridges and mills, devise machines in that area where manpower is scarce. Victim of his zeal to complete the leveling of the river, he perished while trying to cross it above its great falls. ${ }^{\mathrm{xv}}$

30 Had it not been for the death of M. P., we should have been further ahead in our colonization, for we had to wait until another engineer arrived to finish the major landsurveying and the subdivisions. ${ }^{\mathrm{xvi}}$

31 The work that "M. P." would have accomplished is set out in detail, not just to signal what would have been done, but also what still needs to be done, if Castorland is to become a successful and truly prosperous settlement. The Journey mourns and commemorates his death in this passage, which forms a kind of epitaph for Pharoux. It also establishes Pharoux as a kind of human avatar of the castor, the animal that, like Pharoux, was skilled in engineering and hydraulics. ${ }^{\text {xvii }}$

32 Then, the final words of the "Note on Castorland": the promise of a fraternal relation, of a friendship. The "Notes" to Mr. Herman's "Letter" conclude with a quotation from a French neighbor that he is waiting for the arrival of a friend, a brother:

The other day a young Frenchman, my neighbor, 7 miles away, settled for several years on the bank of the river, said to me: “... I am waiting for a friend, rather a brother; ... soon he will arrive from San Domingue where Toussaint-Loverture has permitted him to recoup some of his fortune."xviii

33 Is it reading too much into the Journey to see this document as an attempt to restore positive relations between these two countries? As Crèvecoeur says in the "Translator's Preface," some of his friends were indifferent to the American example; while others felt that there were real lessons given the analogous situation of post-Revolutionary France, when one needed to be "delivered" from the "servitude" of the Revolution. ${ }^{\text {xix }}$

34 The "Notes" to Mr. Herman's "Letter" end on a note of waiting, of expectation. They strike me as having a rhetorical parallel at the Journey's beginning, where we find the "Dedication" to George Washington, the exemplar of the once firm alliance between the United States and France. The anaphora of the beginning that refers to Washington ("The one who ...") is paralleled with an anaphora at the end that refers to the remembrance of friendship: ("Never shall I forget ..."). $x$

35 An "alliance" can be a formal document. It can also be practical cooperation between friends. I suggest that this larger social and political goal is part of the reason for the writing of the Journey; that the Journey seeks rhetorically to re-enact an alliance. If the discovery of the New World and the creation of America is "the most interesting event in modern times, the discovery and the population of this hemisphere" (III: xi), then the history of this "event" includes the history of the practical benefits of alliance, which seem to have overcome the pessimism inherent in human society.

36 To do justice to the idea of "alliance" in Crèveceour, one ought to analyze this idea in the larger context of the various agents that, in Crèvecoeur's writings, promote societal 
good. These agents include people, for example, who possess special "wisdom," whether human or divine, such as George Washington or the Manitou, whose story is told in II: i. Certain things also may be catalysts for the creation of such social order, that is, the various verbal or written agents, such as treaties or compacts, laws, etc., which are mentioned throughout the Journey and which may lead to peace and social tranquillity.

The nature of Crèvecoeur's style and rhetoric is still to be explored. In the Journey, one finds several metaphors used to refer to Crèvecoeur's writing. He speaks for example of need for a verbal painter to do justice in the portrayal of the "picture" of American society. The notion of translation is also one of the various ways that Crèvecoeur names his literary purpose. If a translation requires an original, then the real original of the Journey may be, in part, the Castorland Journal, a text that needed in the late Federalist period to be translated into a more optimistic language, the language of alliance and friendship. ${ }^{x x i}$ How the political and literary debate would continue is another story, one that involves the next century and the names Lafayette and Cooper.

\section{BIBLIOGRAPHY}

Adams, Percy G., “The Historical Value of Crèvecoeur's Voyage dans La Haute Pensylvanie et dans New York", American Literature, Vol. 25, March 1953-January 1954, 152-168.

Adams, Willi Paul, “The Historian as Translator: An Introduction”, Journal of American History, vol. 85, no. 4 (Mar., 1999): 11283-1288.

Chevignard, Bernard, Michel Saint-Jean de Crèvecoeur, Paris, Editions Belin, 2004.

Desjardins, Simon. Diary, 21 September 1795, Castorland Journal, Massachusetts Historical Society.

Elkins, Stanley and Eric McKitrick, The Age of Federalism: The Early American Republic, 1788-1800, Oxford, Oxford University Press, 1993.

Kraus, Michael, "Literary Relations Between Europe and America in the Eighteenth Century", The William and Mary Quarterly, 3rd. Ser., Vol. 1, No. 3, July 1944, 210-234.

Marienstras, Elise, and Naomi Wolf, "French Translations and Reception of the Declaration of Independence”, Journal of American History, vol. 85, no. 4 (Mar., 1999): 1299-1324.

Michel-Guillaume St. Jean de Crèvecoeur, Journey into Northern Pennsylvania and the State of New York, trans. Clarissa Spencer Bostelman, Ann Arbor, The University of Michigan Press, 1964. Mitchell, Julia Post, St. Jean de Crèvecoeur, New York, Columbia University Press, 1916.

O'Neal, John C., Changing Minds: The Shifting Perception of Culture in Eighteenth-Century France, Newark, University of Delaware Press, 2002.

Philbrick, Thomas, St. Jean de Crèvecoeur, New York, Twaine Publishers, 1970.

Plet ,Françoise, ed. Une géographie de l'Amérique du Nord à la fin du XVIIIe siècle: Saint-John de Crèvecoeur, Journey dans la Haute Pensylvnie et dans l'Etat de New-York depuis l'année 1785 
jusqu'en 1798. Edition sélective et critique. Saint-Denis, Presses Universitaires de Vincennes, 2002.

Pilcher, Edith, Castorland: French Refugees in the Western Adirondacks. New York: Purple Mountain Press, 1985.

Rice, Howard C. Le Cultivateur Américain: Etude sur l'oeuvrre de Saint Jean de Crèvecoeur, Paris, Librairie Ancienne Honoré Champion, 1933.

[St. Jean de Crèvecoeur], Voyage dans la Haute Pensylvanie et dans l'Etat de New York. Three volumes. Paris, Chez Maradan, Libraire...An IX [1801]. Case-Geyer Library, Colgate University.

Thelen, David, "Individual Creativity and the Filters of Language and culture: Interpreting the Declaration of Independence by Translation", Journal of American History, vol. 85, no. 4 (Mar., 1999): 1289-1298.

Ziesche, Philip, "Exporting American Revolutions: Gouverneur Morris, Thomas Jefferson, and the National Struggle for Universal Rights in Revolutionary France”, Journal of the Early Republic, Vol. 26, Fall 2006, 419-447.

\section{NOTES}

i. I quote from Michel-Guillaume St. Jean de Crèvecoeur, Journey into Northern Pennsylvania and the State of New York, trans. Clarissa Spencer Bostelman, Ann Arbor, The University of Michigan Press, 1964. I have modified or corrected this translation in a few places by using the original edition of the Journey: [St. Jean de Crèvecoeur], Voyage dans la Haute Pensylvanie et dans l'Etat de New York. Three volumes. Paris, Chez Maradan, Libraire .... An IX [1801]. Case-Geyer Library, Colgate University. For a recent edition of the Journey, see the abridged but useful text by Françoise Plet, éd., Une géographie de l'Amérique du Nord à la fin du XVIIIe siècle: Saint-John de Crèvecoeur, Journey dans la Haute Pensylvnie et dans l'Etat de New-York depuis l'année 1785 jusqu'en 1798. Edition sélective et critique. Saint-Denis: Presses Universitaires de Vincennes, 2002.

ii. Bostelmann 570. I have changed Bostelmann's numbering of the notes to this passage. Note 1 (Castorland) corresponds to Bostelmann's no. 11; Note 2 (Niahouré) corresponds to Bostelmann's no. 12.

iii. Bostelmann 614.

iv. In Volum I: Chapter iii: note 2, Bostelman, 177.

v. For the history of the Castorland venture, see Edith Pilcher, Castorland: French Refugees in the Western Adirondacks, 1793-1814 (Harrison, New York: Harbor Hill Books, 1985). The original manuscript is to be found in the collections of the Massachusetts Historical Society. This essay on Crèvecoeur and the Castorland Journal emerges from my work on the translation and editing of the Castorland Journal for publication.

vi. See Pilcher 173-175. This period of Crèvecoeur's life is relatively unknown. See the biographies by Rice, Philbrick and Mitchell listed in the Bibliography.

vii. See Pilcher on the discovery of the Journal.

viii. Cf. Plet 18.

ix. Bostelmann 169.

x. Bostelmann 171. For some unknown reason, Bostelmann translates mistakenly: "an alliance, which as it turned out, was useless for them...."

xi. Bostelmann 604.

xii. Bostelmann 557. I have modified the translation (change indicated in square brackets).

xiii. The studies of this period are numerous. See in particular Stanley Elkins and Eric McKitrick, The Age of Federalism: The Early American Republic, 1788-1800 (Oxford, Oxford University Press, 1993). 
xiv. Bostelmann 616.

xv. Bostelmann 616. Crèvecoeur alters a few details in the account given of Pharoux's death as given in the Castorland Journal. See Simon Desjardsin, diary, 21 September 1795, Castorland Journal, Massachusettes Historical Society. Pharoux was drowned while crossing the Black River, but in the Journal, the drowning occurs as a result of Pharoux's eagerness to travel to Kingston, Canada. Crèvecoeur alters slightly the details to emphasize Pharoux as engineer.

xvi. Bostelmann 618.

xvii. See Bostelmann, 233. See the symbolic value of the beaver in eighteenth-century French thought in John O'Neal, Changing Minds: The Shifting Perception of Culture in Eighteenth-Century France (Newark, University of Delaware Press, 2002) 18.

xviii. Bostelmann 619.

xix. Bostelmann 619.

xx. Bostelmann xiii-xiv and 570-571, respectively.

xxi. The question of translation and its applicability to American political history of this period has become a subject of interesting scholarship. See Elise Marienstras and Naomi Wolf, "French Translations and Reception of the Declaration of Independence," Journal of American History 85: 4 (Mar. 1999): 1299-1324; David Thelen, "Individual Creativity and the Filters of Language and culture: Interpreting the Declaration of Independence by Translation," ibid.: 1289-1298; Philip Ziesche, Exporting American Revolutions, ibid.: 419-417; Willi Paul Adams, "The Historian as Translator: An Introduction,"ibid.: 1283-1288.

\section{INDEX}

Keywords: Black River, Castorland, Castorland Journal, Compagnie de New York (New York Company), Émigrés, Exploration, French Revolution, French-American alliance, land-surveying, New York State, settlement, speculation, translation 